\title{
Nocardiopsis alkaliphila sp. nov., a novel alkaliphilic actinomycete isolated from desert soil in Egypt
}

\author{
Wael N. Hozzein, ${ }^{1}$ Wen-Jun Li, ${ }^{2}$ Mohammed Ibrahim A. Ali, ${ }^{1}$ \\ Ola Hammouda, ${ }^{1}$ Ahmed S. Mousa, ${ }^{1}$ Li-Hua $\mathrm{Xu}^{2}$ and Cheng-Lin Jiang ${ }^{2}$ \\ ${ }^{1}$ Botany Department, Faculty of Science, Cairo University, Beni-Suef, Egypt \\ ${ }^{2}$ Key Laboratory for Microbial Resources of the Ministry of Education, Laboratory for \\ Conservation and Utilization of Bio-resources, Yunnan Institute of Microbiology, Yunnan \\ University, Kunming 650091, P.R. China
}

\begin{abstract}
An alkaliphilic actinomycete strain, designated YIM $80379^{\top}$, was isolated from a soil sample collected from the eastern desert of Egypt and subjected to polyphasic taxonomy. The strain produced substrate and aerial mycelia on different media, with an optimum $\mathrm{pH}$ for growth of 9.5-10 and scarce or no growth at $\mathrm{pH}$ 7. Strain YIM $80379^{\top}$ contained meso-diaminopimelic acid, no diagnostic sugars, type PIII phospholipids and MK-10 $\left(\mathrm{H}_{6}\right)$ and MK-10 $\left(\mathrm{H}_{8}\right)$ as the predominant menaquinones. All of these characters assign isolate YIM $80379^{\top}$ consistently to the genus Nocardiopsis. This was confirmed by $16 \mathrm{~S}$ rDNA analysis. It can be differentiated from all Nocardiopsis species with validly published names by phenotypic characteristics, phylogenetic analysis and DNA-DNA hybridization results. On the basis of polyphasic evidence, a novel species, Nocardiopsis alkaliphila sp. nov., is proposed. The type strain of the species is YIM $80379^{\top}\left(=\right.$ CCTCC AA001031 ${ }^{\top}=$ DSM $\left.44657^{\top}\right)$.
\end{abstract}

Although alkaliphilic bacteria have been studied extensively for a long time, work on alkaliphilic actinomycetes is very rare. This is clear from the fact that very few articles about alkaliphilic actinomycetes have been published previously (Miyashita et al., 1984; Groth et al., 1997; Duckworth et al., 1998; Kroppenstedt \& Evtushenko, 2002). It is therefore important to pay more attention to this group of extreme actinomycetes, as a possible way to discover novel taxa and, consequently, new secondary metabolites. It was reported that most of the alkaliphilic actinomycetes that have been isolated belong to the genus Nocardiopsis (Mikami et al., 1982, 1986; Kroppenstedt \& Evtushenko, 2002); most Nocardiopsis species are alkaliphilic, as their growth optimum is above $\mathrm{pH} 8 \cdot 0$, and the genus Nocardiopsis contained 16 species with validly published names at the time of writing (Meyer, 1976; Grund \& Kroppenstedt, 1990; Yassin et al., 1993, 1997; Al-Tai \& Ruan, 1994; Chun et al., 2000; Evtushenko et al., 2000; Peltola et al., 2001; Al-Zarban et al., 2002; Kämpfer et al., 2002; Schippers et al., 2002;

Published online ahead of print on 1 August 2003 as DOI 10.1099/ ijs.0.02832-0.

Abbreviations: DPG, diphosphatidylglycerol; PC, phosphatidylcholine; PE, phosphatidylethanolamine; PG, phosphatidylglycerol; PIM, phosphatidylinositol mannosides; PME, phosphatidyl methylethanolamine.

The GenBank/EMBL/DDBJ accession number for the 16S rDNA sequence of strain $\mathrm{YIM} 80379^{\top}$ is $\mathrm{AY} 230848$.
Li et al., 2003). In this study, a novel alkaliphilic actinomycete was identified by a polyphasic approach and was found to be a novel species of the genus Nocardiopsis. The name Nocardiopsis alkaliphila sp. nov. is proposed.

Strain YIM $80379^{\mathrm{T}}$ was isolated from a soil sample collected from the eastern desert of Egypt by using medium A, which was recommended by Sato et al. (1983) for the isolation of alkaliphilic and alkaline-resistant micro-organisms. This medium contained $\left(\mathrm{g} \mathrm{l}^{-1}\right)$ : glucose, $10 \cdot 0$; peptone, $5 \cdot 0$; yeast extract, $5 \cdot 0 ; \mathrm{K}_{2} \mathrm{HPO}_{4} .3 \mathrm{H}_{2} \mathrm{O}, 1 \cdot 0 ; \mathrm{MgSO}_{4} .7 \mathrm{H}_{2} \mathrm{O}, 0 \cdot 2$; $\mathrm{Na}_{2} \mathrm{CO}_{3}, 10 \cdot 0$; and agar, $15 \cdot 0$. Sodium carbonate was sterilized separately and then added to the medium. The $\mathrm{pH}$ of the medium was $10 \cdot 0-10 \cdot 5 ; \mathrm{NaHCO}_{3} / \mathrm{Na}_{2} \mathrm{CO}_{3}$ buffer was used to adjust the $\mathrm{pH}$. After incubation at $28^{\circ} \mathrm{C}$ for 14 days, a visible colony (designated YIM $80379^{\mathrm{T}}$ ) was picked and subcultured until purification. A preliminary test was carried out to confirm its requirement for alkalinity; it was unable to grow below $\mathrm{pH} 7 \cdot 0$. The strain was maintained in $20 \%$ glycerol and kept at $-20^{\circ} \mathrm{C}$.

The isolate was cultivated on medium A and yeast extract/ malt extract agar (ISP 2), both at $\mathrm{pH} 10 \cdot 0$, and used for microscopic observations of the sporophores, spore-chains and spore surface by using light and scanning electron microscopes (JEOL, JSM-5600LV). Cultural characteristics were studied on ISP media (Shirling \& Gottlieb, 1966), medium A (Sato et al., 1983), Czapek's agar (Waksman, 
1967), modified Bennet's medium (Jones, 1949) and nutrient agar (Waksman, 1961). All media were solidified with $2 \cdot 0 \%$ agar and their $\mathrm{pH}$ was adjusted to $9 \cdot 5-10 \cdot 0$; after incubation for 28 days at $28^{\circ} \mathrm{C}$, the colours of both substrate and aerial mycelia and the production of soluble pigments were determined by comparison with chips from ISCC-NBS colour charts (Kelly, 1964).

For chemotaxonomic studies, strain YIM $80379^{\mathrm{T}}$ was grown in medium A broth on a shaking incubator at 200 r.p.m. and $28{ }^{\circ} \mathrm{C}$ for 7 days. Mycelia and cells were harvested by centrifugation, washed three times with distilled water and then freeze-dried. Amino acid and sugar analyses of wholecell hydrolysates were performed as described by Hasegawa et al. (1983) and Staneck \& Roberts (1974), respectively. Polar lipids were extracted and detected by previously described methods (Minnikin et al., 1977; Lechevalier \& Lechevalier, 1980). Menaquinones were extracted, purified and identified by HPLC as described by Collins (1985).

All physiological tests were done at $28^{\circ} \mathrm{C}$ and $\mathrm{pH} 9 \cdot 5-10 \cdot 0$ unless otherwise specified. Production of melanoid pigments was tested on ISP media, as described by Shirling \& Gottlieb (1966). Carbon source utilization was examined on ISP 9 as a basal medium (Shirling \& Gottlieb, 1966), supplemented with a final concentration of $1 \%$ of the tested carbon sources (except for sodium acetate, sodium citrate and sodium succinate, which were used at a final concentration of $0 \cdot 1 \%$ ). Utilization of different nitrogen sources, catalase production and degradation of tyrosine, hypoxanthine, casein, starch and gelatin were detected in modified Bennett's agar medium (MBA) after 7, 14 and 21 days, as described by Williams et al. (1983). Hydrogen sulphide production was detected by the method of Küster \& Williams (1964). The effect of different temperatures and $\mathrm{pH}$ levels on growth and tolerance to salt $(\mathrm{NaCl}$ at 5,10 and $15 \%, w / v)$ was determined by using MBA or medium $\mathrm{A}$ as a basal medium.

DNA was extracted for $16 \mathrm{~S}$ rDNA analysis by the method described by Orsini \& Romano-Spica (2001). PCRmediated amplification of $16 \mathrm{~S}$ rDNA, purification of PCR products and sequencing of purified products were done as described previously (Cui et al., 2001). The resultant sequence was aligned manually against bacterial sequences that were available in public databases. A more detailed comparison was performed with members of the genus Nocardiopsis and evolutionary distance matrices were calculated by the method of Jukes \& Cantor (1969). Phylogenetic trees were inferred by using the neighbourjoining (Saitou \& Nei, 1987) and maximum-likelihood (Felsenstein, 1981) methods. Bootstrap analysis was used to evaluate the tree topology of the neighbour-joining data by performing 1000 resamplings (Felsenstein, 1985).

DNA was isolated according to Hopwood et al. (1985) and its $\mathrm{G}+\mathrm{C}$ content was determined by the thermal denaturation method (Mandel \& Marmur, 1968) with a Shimadzu UV-visible spectrophotometer (UV1601). DNA-DNA hybridization was carried out spectrophotometrically, as described by De Ley et al. (1970).

Alkaliphilic strain YIM $80379^{\mathrm{T}}$ showed good growth on most agar media used (Table 1). Aerial mycelium was abundant on most media and its colour varied from white to yellowish-white. Substrate mycelium was light yellow to yellowish-brown; no soluble pigments were produced on any medium. Mature aerial mycelium fragmented to branched and straight spore-chains with elongated, irregular and smooth spores (Fig. 1).

The isolate's membership of the genus Nocardiopsis was confirmed by cell chemistry. Whole-cell hydrolysates contained meso-diaminopimelic acid as the only peptidoglycan diamino acid and ribose and glucose as the only sugars, but no diagnostic sugars such as arabinose, xylose, madurose (Lechevalier et al., 1971) or rhamnose (Labeda et al., 1984). This leads to cell wall type III and sugar pattern C (Lechevalier \& Lechevalier, 1970). The polar lipid pattern revealed the presence of phosphatidylcholine

Table 1. Cultural characteristics of strain YIM $80379^{\top}$

\begin{tabular}{|llll|}
\hline Medium $^{\star}$ & Growth & Aerial mycelium & Substrate mycelium \\
\hline Tryptone/yeast extract (ISP 1) & Poor & - & Light yellow $\dagger$ \\
Yeast extract/malt extract (ISP 2) & Moderate & White & Yellowish-brown \\
Oatmeal agar (ISP 3) & Abundant & Yellowish-white & Yellowish-brown \\
Inorganic salts/starch agar (ISP 4) & Good & White & Pale yellow \\
Glycerol/asparagine agar (ISP 5) & Good & White & Pale yellow \\
Tyrosine agar (ISP 7) & Abundant & Yellowish-white & Yellow \\
Bennet agar & Moderate & White & Greyish-yellow \\
Czapek agar & Abundant & Yellowish-white & Soft yellow \\
Nutrient agar & Good & Yellowish-white & Pale yellow \\
Sato A & Abundant & Yellowish-white & Deep yellow \\
\hline
\end{tabular}

*All media were adjusted to $\mathrm{pH} 9 \cdot 5-10 \cdot 0$. ISP, International Streptomyces Project (Shirling \& Gottlieb, 1966).

†Colours were taken from ISCC-NBS colour charts (Kelly, 1964). 


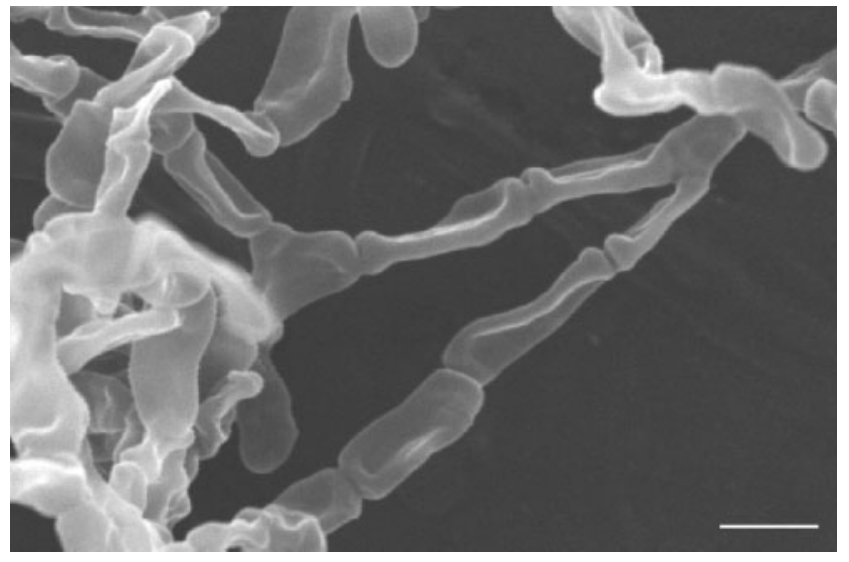

Fig. 1. Scanning electron micrograph of strain YIM $80379^{\top}$ after growth on medium $A$ for 14 days at $28^{\circ} \mathrm{C}$. Bar, $1 \mu \mathrm{m}$.

(PC), phosphatidylglycerol (PG), phosphatidyl methylethanolamine (PME), phosphatidylethanolamine (PE), phosphatidylinositol mannosides (PIM), diphosphatidylglycerol (DPG), an unknown glycolipid and about four unknown phospholipids with high $R_{\mathrm{f}}$ values (above that of DPG). The phospholipid pattern is type PIII according to Lechevalier et al. (1977), with PC as the diagnostic phospholipid. This phosopholipid type is found in species of the genera Nocardiopsis, Actinopolyspora, Pseudonocardia and Saccharopolyspora. However, Nocardiopsis strains are easily differentiated from these other taxa by the presence of PME, high amounts of PG, lack of hydroxy-PE and the detection of unknown phospholipids with high $R_{\mathrm{f}}$ values (above that of DPG). These unknown phospholipids are of diagnostic value and, until now, have only been found in Nocardiopsis species (Kroppenstedt, 1992).

Strain YIM $80379^{\mathrm{T}}$ synthesized a complex pattern of menaquinones with 9,10 and 11 isoprenoid units in the side chain and a variable degree of saturation. Major menaquinones were MK-10 $\left(\mathrm{H}_{6}\right)$, MK-10 $\left(\mathrm{H}_{8}\right)$, MK-11( $\left.\mathrm{H}_{2}\right)$, MK$9\left(\mathrm{H}_{6}\right)$, MK- $9\left(\mathrm{H}_{10}\right)$ and MK-10 $\left(\mathrm{H}_{4}\right)$. Minor menaquinones were MK-11 $\left(\mathrm{H}_{4}\right)$, MK-9 $\left(\mathrm{H}_{2}\right)$, MK-9 $\left(\mathrm{H}_{4}\right)$ and MK-10 $\left(\mathrm{H}_{2}\right)$. Trace amounts of some other menaquinones were also found. This quinone system, with the predominant menaquinones MK-10 $\left(\mathrm{H}_{6}\right)$, MK-10 $\left(\mathrm{H}_{8}\right)$ and other MK-10 menaquinones, is characteristic of species of the genus Nocardiopsis. Also, such a complex quinone system, or one even more complicated, was reported in earlier studies (Evtushenko et al., 2000; Al-Zarban et al., 2002; Kämpfer et al., 2002). All these characteristics are typical of the genus Nocardiopsis (Grund \& Kroppenstedt, 1990; Kroppenstedt, 1992).

No melanoid pigments were produced. Arabinose, xylose, maltose, cellobiose, raffinose and sucrose were utilized as good carbon sources, but weak utilization was observed with glucose, galactose, lactose, rhamnose, xylitol, sorbitol, inositol, dulcitol, sodium citrate and sodium succinate. Ribose, fructose, mannose, mannitol and sodium acetate were not utilized. Growth on potassium nitrate, asparagine, phenylalanine and serine as nitrogen sources was recorded, but histidine, methionine, valine, threonine, cysteine and glycine were utilized weakly, whereas growth on arginine and hydroxyproline was not observed. Strain YIM $80379^{\mathrm{T}}$ could degrade tyrosine, hypoxanthine, casein, gelatin, starch and tributrin; it also produced catalase, but not $\mathrm{H}_{2} \mathrm{~S}$. Temperature range for growth was $10-45^{\circ} \mathrm{C}$; it showed optimum growth at $28-30{ }^{\circ} \mathrm{C}$. It grew only on alkaline media. No growth was observed below $\mathrm{pH} 7 \cdot 0$ and the optimum $\mathrm{pH}$ for growth was $9 \cdot 5-10 \cdot 0$. The maximum $\mathrm{pH}$ for growth was $12 \cdot 0$. Good growth was shown at $\mathrm{NaCl}$ concentrations up to $10 \cdot 0 \%$.

The almost-complete 16S rDNA sequence of strain YIM $80379^{\mathrm{T}}$, which consisted of $1490 \mathrm{bp}$, was determined. Preliminary comparison of the sequence against those in GenBank indicated that members of the genus Nocardiopsis were the closest phylogenetic neighbours. Binary similarity values of this strain and other species of the genus Nocardiopsis ranged between $95.4 \%$ (Nocardiopsis halophila DSM $44494^{\mathrm{T}}$ ) and $98.5 \%$ (Nocardiopsis prasina DSM $43845^{\mathrm{T}}$ ). Pairwise similarity values $>97 \%$ were also found for Nocardiopsis listeri DSM $40297^{\mathrm{T}}(98 \cdot 4 \%)$, Nocardiopsis metallicus DSM $44598^{\mathrm{T}}(98 \cdot 2 \%)$, Nocardiopsis exhalans DSM $44407^{\mathrm{T}}(98 \cdot 1 \%)$, Nocardiopsis alba DSM $43377^{\mathrm{T}}$ $(97 \cdot 8 \%)$, Nocardiopsis lucentensis DSM $44048^{\mathrm{T}}(97 \cdot 7 \%)$, Nocardiopsis dassonvillei subsp. dassonvillei DSM $43111^{\mathrm{T}}$ $(97 \cdot 7 \%)$, Nocardiopsis umidischolae DSM $43662^{\mathrm{T}}(97 \cdot 1 \%)$ and Nocardiopsis synnemataformans DSM $44143^{\mathrm{T}}(97 \cdot 2 \%)$. These 16S rDNA sequence similarity values are approximately the same or less than the similarity values between closely related Nocardiopsis species, such as $N$. dassonvillei and N. synnemataformans $(99 \cdot 3 \%), N$. metallicus and N. exhalans $(99 \cdot 4 \%), N$. alba and N. prasina $(99.0 \%)$, N. halotolerans and N. dassonvillei $(98.4 \%)$ and N. listeri and N. prasina $(98 \cdot 8 \%)$. A phylogenetic tree of Nocardiopsis species is shown in Fig. 2. The closest phylogenetic neighbours of strain YIM $80379^{\mathrm{T}}$ are N. listeri DSM $40297^{\mathrm{T}}$, N. prasina DSM $43845^{\mathrm{T}}$, N. metallicus DSM $44598^{\mathrm{T}}$ and N. exhalans DSM $44407^{\mathrm{T}}$. These data indicate that strain YIM $80379^{\mathrm{T}}$ probably belongs to a novel species. However, sequence similarity values of $\geqslant 97 \%$ was reported to be of limited usefulness in species differentiation, and DNA pairing studies need to be performed to confirm the species affiliation (Stackebrandt \& Goebel, 1994).

DNA of strain YIM $80379^{\mathrm{T}}$ was hybridized against that of $N$. prasina DSM $43845^{\mathrm{T}}$, N. listeri DSM $40297^{\mathrm{T}}$, N. metallicus DSM $44598^{\mathrm{T}}$ and N. exhalans DSM $44407^{\mathrm{T}}$, which were the closest phylogenetic neighbours in the same subclade. DNA-DNA relatedness between strain YIM $80379^{\mathrm{T}}$ and the latter four strains was $42,58,18$ and $35 \%$, respectively. These values are below the value of $70 \%$ that was recommended by Wayne et al. (1987) for strains of the same species. The DNA G + C content of strain YIM $80379^{\mathrm{T}}$ was 


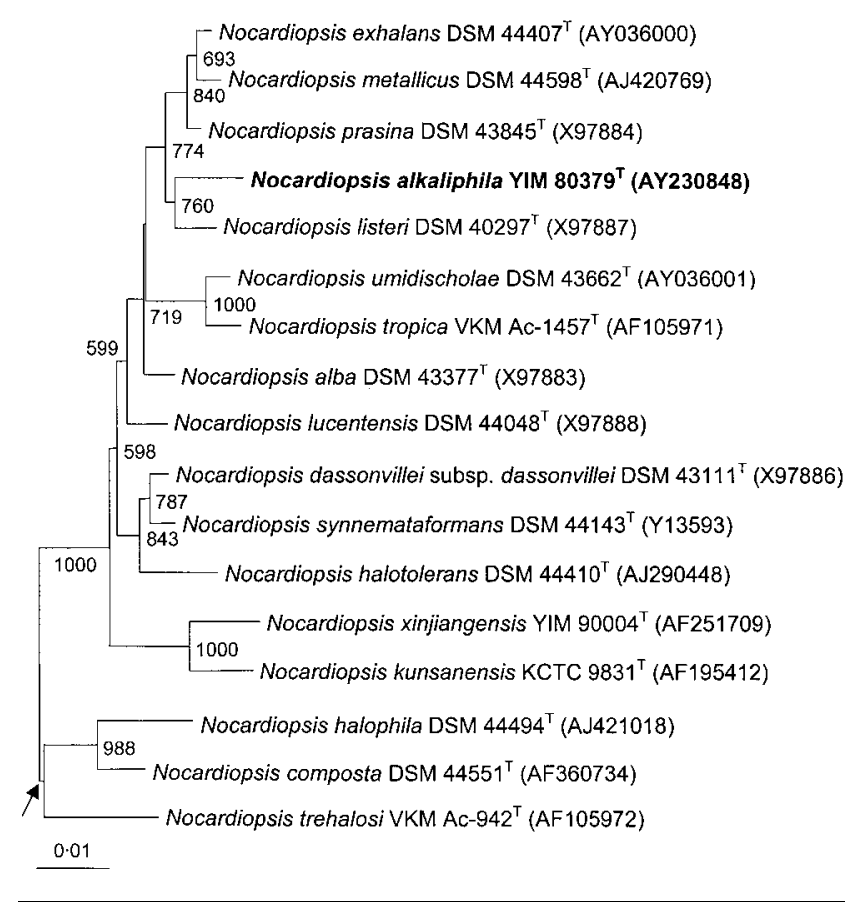

Fig. 2. Phylogenetic dendrogram based on $16 \mathrm{~S}$ rDNA sequence analysis, reconstructed from evolutionary distances by using the neighbour-joining method, showing the phylogenetic position of strain YIM $80379^{\top}$ within the genus Nocardiopsis. The sequence of Actinomadura madurae DSM $43067^{\top}$ (GenBank no. X97889) was used as the outgroup (not shown). Arrow indicates the position of the root. Bar, one inferred nucleotide substitution per $100 \mathrm{nt}$.
$65.8 \mathrm{~mol} \%$, which lies within the range for the genus Nocardiopsis (Grund \& Kroppenstedt, 1990).

Morphological and phylogenetic analyses and chemotaxonomic features clearly provided evidence that strain YIM $80379^{\mathrm{T}}$ belongs to the genus Nocardiopsis. The phylogenetic position of this strain is within a cluster that contains N. listeri, N. prasina, N. metallicus and N. exhalans. However, strain YIM $80379^{\mathrm{T}}$ can be differentiated from all these species by its ability to grow at $45^{\circ} \mathrm{C}$ and $\mathrm{pH} 12 \cdot 0$, and by a combination of morphological, physiological and chemotaxonomic characteristics (Table 2). Also, it can be differentiated easily from $N$. listeri and $N$. prasina, its closest phylogenetic neighbours, by chemotaxonomy: the predominant menaquinones in $N$. listeri are $\mathrm{MK}-10\left(\mathrm{H}_{0}-\mathrm{H}_{2}\right)$ and those in $N$. prasina are $\mathrm{MK}-10\left(\mathrm{H}_{4}-\mathrm{H}_{6}\right)$, whilst those in YIM $80379^{\mathrm{T}}$ are $\mathrm{MK}-10\left(\mathrm{H}_{6}-\mathrm{H}_{8}\right)$. It can also be distinguished by morphology from $N$. listeri, which does not produce a well-developed aerial mycelium. Furthermore, DNA-DNA reassociation values determined for strain YIM $80379^{\mathrm{T}}$ with $N$. listeri and N. prasina were only 42 and $58 \%$, which reinforces the genomic differences between them.

Based on the above phenotypic and genotypic results, it is concluded that isolate YIM $80379^{\mathrm{T}}$ merits species status in the genus Nocardiopsis; the name Nocardiopsis alkaliphila sp. nov. is proposed for this isolate, with the type strain YIM $80379^{\mathrm{T}}\left(=\right.$ CCTCC AA001031 ${ }^{\mathrm{T}}=$ DSM $\left.44657^{\mathrm{T}}\right)$.

\section{Description of Nocardiopsis alkaliphila sp. nov.}

Nocardiopsis alkaliphila (al.ka.li'phi.la. N.L. n. alkali from Arabic al-qaliy the ashes of saltwort; Gr. adj. philos friendly, loving; N.L. fem. adj. alkaliphila loving alkaline environments).

Table 2. Characteristics that differentiate strain $\mathrm{YIM} 80379^{\top}$ from the phylogenetically most closely related Nocardiopsis species

Taxa: 1, YIM $80379^{\mathrm{T}}$; 2, N. listeri; 3, N. prasina; 4, N. exhalans; 5, N. metallicus. Data are from Yassin et al. (1997), Peltola et al. (2001), Schippers et al. (2002) and the present study.

\begin{tabular}{|c|c|c|c|c|c|}
\hline Characteristic & 1 & 2 & 3 & 4 & 5 \\
\hline Aerial mycelium & + & - & + & + & + \\
\hline \multicolumn{6}{|l|}{ Utilization of: } \\
\hline D-Galactose & \pm & - & - & - & + \\
\hline D-Fructose & - & + & - & + & ND \\
\hline D-Sucrose & + & + & - & + & + \\
\hline L-Rhamnose & \pm & + & - & + & + \\
\hline Acetate & - & - & + & + & + \\
\hline L-Serine & + & + & + & + & - \\
\hline Degradation of hypoxanthine & + & + & - & ND & ND \\
\hline \multicolumn{6}{|l|}{ Growth at: } \\
\hline $10^{\circ} \mathrm{C}$ & + & + & - & + & \pm \\
\hline $45^{\circ} \mathrm{C}$ & + & - & - & - & - \\
\hline $\mathrm{pH} 12 \cdot 0$ & + & ND & - & ND & - \\
\hline Major menaquinones* & $10 / 6,10 / 8$ & $10 / 0,10 / 2$ & $10 / 4,10 / 6$ & $10 / 6,10 / 8$ & ND \\
\hline
\end{tabular}

${ }^{\star} 10 / 6, \mathrm{MK}-10\left(\mathrm{H}_{6}\right)$ and so on. 
Aerobic, Gram-positive, non-acid-fast, non-motile organism. Aerial mycelium is white to yellowish-white. Substrate mycelium is yellow to yellowish-brown. Diffusible pigments are not produced. Mature aerial mycelium fragments to branched and straight spore-chains with elongated, irregular and smooth spores. Whole-cell hydrolysates contain mesodiaminopimelic acid and the sugars glucose and ribose. Polar lipid pattern is composed of PC, PG, PME, PE, PIM, DPG, an unknown glycolipid and about four unknown phospholipids with high $R_{\mathrm{f}}$ values. Major menaquinones are $\mathrm{MK}-10\left(\mathrm{H}_{6}\right)$, MK-10 $\left(\mathrm{H}_{8}\right)$, MK-11( $\left.\mathrm{H}_{2}\right)$, MK-9(H $\left.\mathrm{H}_{6}\right)$, MK$9\left(\mathrm{H}_{10}\right)$ and MK-10 $\left(\mathrm{H}_{4}\right)$; minor menaquinones $\mathrm{MK}-11\left(\mathrm{H}_{4}\right)$, MK-9 $\left(\mathrm{H}_{2}\right)$, MK-9 $\left(\mathrm{H}_{4}\right)$ and MK-10 $\left(\mathrm{H}_{2}\right)$ are also detected. Melanin is not produced. Arabinose, xylose, maltose, cellobiose, raffinose and sucrose are utilized as good carbon sources, but weak utilization of glucose, galactose, lactose, rhamnose, xylitol, sorbitol, inositol, dulcitol, sodium citrate and sodium succinate is observed. Ribose, fructose, mannose, mannitol and sodium acetate are not utilized. Growth on potassium nitrate, asparagine, phenylalanine and serine as nitrogen sources is recorded, but histidine, methionine, valine, threonine, cysteine and glycine are utilized only weakly, whereas growth on arginine and hydroxyproline is not observed. Able to degrade hypoxanthine, tyrosine, casein, gelatin, starch and tributrin. Catalase is produced, but $\mathrm{H}_{2} \mathrm{~S}$ is not. Growth occurs at $10-45^{\circ} \mathrm{C}$, pH $7 \cdot 0-12 \cdot 0$ and $0-10 \cdot 0 \% \mathrm{NaCl}$, with optimum growth at $28-30{ }^{\circ} \mathrm{C}, \mathrm{pH} 9 \cdot 5-10 \cdot 0$ and $2 \cdot 5 \% \mathrm{NaCl}$. DNA $\mathrm{G}+\mathrm{C}$ content is $65 \cdot 8 \mathrm{~mol} \%$.

The type strain is YIM $80379^{\mathrm{T}}\left(=\right.$ CCTCC AA001031 ${ }^{\mathrm{T}}=$ DSM $\left.44657^{\mathrm{T}}\right)$. Isolated from desert soil in Egypt.

\section{Acknowledgements}

The authors are grateful to R. M. Kroppenstedt for kindly providing type strains of the genus Nocardipsis. This research was supported by the Ministry of Science and Technology, P.R. China (project no. 2001CCC00600), the National Natural Science Foundation of China (project no. 30270004), Yunnan Provincial Natural Science Foundation (project no. 20001C001Q) and Yunnan Education Foundation (project nos 01111134 and 02QJ077).

\section{References}

Al-Tai, A. M. \& Ruan, J.-S. (1994). Nocardiopsis halophila sp. nov., a new halophilic actinomycete isolated from soil. Int J Syst Bacteriol 44, 474-478.

Al-Zarban, S. S., Abbas, I., Al-Musallam, A. A., Steiner, U., Stackebrandt, E. \& Kroppenstedt, R. M. (2002). Nocardiopsis halotolerans sp. nov., isolated from salt march soil in Kuwait. Int J Syst Evol Microbiol 52, 525-529.

Chun, J., Bae, K. S., Moon, E. Y., Jung, S.-O., Lee, H. K. \& Kim, S.-J. (2000). Nocardiopsis kunsanensis sp. nov., a moderately halophilic actinomycete isolated from a saltern. Int J Syst Evol Microbiol 50, 1909-1913.

Collins, M. D. (1985). Isoprenoid quinone analysis in bacterial classification and identification. In Chemical Methods in Bacterial Systematics, pp. 267-287. Edited by M. Goodfellow \& D. E. Minnikin. London: Academic Press.
Cui, X.-L., Mao, P.-H., Zeng, M., Li, W.-J., Zhang, L.-P., Xu, L.-H. \& Jiang, C.-L. (2001). Streptimonospora salina gen. nov., sp. nov., a new member of the family Nocardiopsaceae. Int J Syst Evol Microbiol 51, 357-363.

De Ley, J., Cattoir, H. \& Reynaerts, A. (1970). The quantitative measurement of DNA hybridization from renaturation rates. Eur $J$ Biochem 12, 133-142.

Duckworth, A. W., Grant, S., Grant, W. D., Jones, B. E. \& Meijer, D. (1998). Dietzia natronolimnaios sp. nov., a new member of the genus Dietzia isolated from an east African soda lake. Extremophiles 2, 359-366.

Evtushenko, L. I., Taran, V. V., Akimov, V. N., Kroppenstedt, R. M., Tiedje, J. M. \& Stackebrandt, E. (2000). Nocardiopsis tropica sp. nov., Nocardiopsis trehalosi sp. nov., nom. rev. and Nocardiopsis dassonvillei subsp. albirubida subsp. nov., comb. nov. Int J Syst Evol Microbiol 50, 73-81.

Felsenstein, J. (1981). Evolutionary trees from DNA sequences: a maximum likelihood approach. J Mol Evol 17, 368-376.

Felsenstein, J. (1985). Confidence limits on phylogenies: an approach using the bootstrap. Evolution 39, 783-791.

Groth, I., Schumann, P., Rainey, F. A., Martin, K., Schuetze, B. \& Augsten, K. (1997). Bogoriella caseilytica gen. nov., sp. nov., a new alkaliphilic actinomycete from a soda lake in Africa. Int J Syst Bacteriol 47, 788-794.

Grund, E. \& Kroppenstedt, R. M. (1990). Chemotaxonomy and numerical taxonomy of the genus Nocardiopsis Meyer 1976. Int J Syst Bacteriol 40, 5-11.

Hasegawa, T., Takizawa, M. \& Tanida, S. (1983). A rapid analysis for chemical grouping of aerobic actinomycetes. J Gen Appl Microbiol 29, 319-322.

Hopwood, D. A., Bibb, M. J., Chater, K. F., Kieser, T., Bruton, C. J., Kieser, H. M., Lydiate, D. J., Smith, C. P. \& Ward, J. M. (1985). Preparation of chromosomal, plasmid and phage DNA. In Genetic Manipulation of Streptomyces - a Laboratory Manual, pp. 79-80. Norwich, UK: F. Crowe \& Sons.

Jones, K. L. (1949). Fresh isolates of actinomycetes in which the presence of sporogenous aerial mycelia is a fluctuating characteristic. $J$ Bacteriol 57, 141-146.

Jukes, T. H. \& Cantor, C. R. (1969). Evolution of protein molecules. In Mammalian Protein Metabolism, pp. 21-132. Edited by H. N. Munro. New York: Academic Press.

Kämpfer, P., Busse, H.-J. \& Rainey, F. A. (2002). Nocardiopsis compostus sp. nov., from the atmosphere of a composting facility. Int J Syst Evol Microbiol 52, 621-627.

Kelly, K. L. (1964). Inter-Society Color Council-National Bureau of Standards Color Name Charts Illustrated with Centroid Colors. Washington, DC: US Government Printing Office.

Kroppenstedt, R. M. (1992). The genus Nocardiopsis. In The Prokaryotes, 2nd edn, pp. 1139-1156. Edited by A. Balows, H. G. Trüper, M. Dworkin, W. Harder \& K.-H. Schleifer. New York: Springer.

Kroppenstedt, R. M. \& Evtushenko, L. I. (2002). The family Nocardiopsaceae. In The Prokaryotes. A Handbook on the Biology of Bacteria: Ecophysiology, Isolation, Identification, Applications. Edited by M. Dworkin, S. Falkow, E. Rosenberg, K. H. Schleifer \& E. Stackebrandt. New York: Springer.

Küster, E. \& Williams, S. T. (1964). Production of hydrogen sulfide by streptomycetes and methods for its detection. Appl Microbiol 12, $46-52$.

Labeda, D. P., Testa, R. T., Lechevalier, M. P. \& Lechevalier, H. A. (1984). Saccharothrix: a new genus of the Actinomycetales related to Nocardiopsis. Int J Syst Bacteriol 34, 426-431. 
Lechevalier, M. P. \& Lechevalier, H. (1970). Chemical composition as a criterion in the classification of aerobic actinomycetes. Int J Syst Bacteriol 20, 435-443.

Lechevalier, M. P. \& Lechevalier, H. A. (1980). The chemotaxonomy of actinomycetes. In Actinomycete Taxonomy, pp. 227-291. Edited by A. Dietz \& D. W. Thayer. Arlington, VA: Society For Industrial Microbiology.

Lechevalier, H. A., Lechevalier, M. P. \& Gerber, N. N. (1971). Chemical composition as a criterion in the classification of actinomycetes. Adv Appl Microbiol 14, 47-72.

Lechevalier, M. P., De Bièvre, C. \& Lechevalier, H. A. (1977). Chemotaxonomy of aerobic actinomycetes: phospholipid composition. Biochem Syst Ecol 5, 249-260.

Li, M.-G., Li, W.-J., Xu, P., Cui, X.-L., Xu, L.-H. \& Jiang, C.-L. (2003). Nocardiopsis xinjiangensis sp. nov., a halophilic actinomycete isolated from a saline soil sample in China. Int J Syst Evol Microbiol 53, 317-321.

Mandel, M. \& Marmur, J. (1968). Use of ultraviolet absorbance temperature profile for determining the guanine plus cytosine content of DNA. Methods Enzymol 12B, 195-206.

Meyer, J. (1976). Nocardiopsis, a new genus of the order Actinomycetales. Int J Syst Bacteriol 26, 487-493.

Mikami, Y., Miyashita, K. \& Arai, T. (1982). Diaminopimelic acid profiles of alkalophilic and alkaline-resistant strains of actinomycetes. J Gen Microbiol 128, 1709-1712.

Mikami, Y., Miyashita, K. \& Arai, T. (1986). Alkaliphilic actinomycetes. Actinomycetes 19, 176-191.

Minnikin, D. E., Patel, P. V., Alshamaony, L. \& Goodfellow, M. (1977). Polar lipid composition in the classification of Nocardia and related bacteria. Int J Syst Bacteriol 27, 104-117.

Miyashita, K., Mikami, Y. \& Arai, T. (1984). Alkalophilic actinomycete, Nocardiopsis dassonvillei subsp. prasina subsp. nov., isolated from soil. Int J Syst Bacteriol 34, 405-409.

Orsini, M. \& Romano-Spica, V. (2001). A microwave-based method for nucleic acid isolation from environmental samples. Lett Appl Microbiol 33, 17-20.

Peltola, J. S. P., Andersson, M. A., Kämpfer, P., Auling, G., Kroppenstedt, R. M., Busse, H.-J., Salkinoja-Salonen, M. S. \& Rainey, F. A. (2001). Isolation of toxigenic Nocardiopsis strains from indoor environments and description of two new Nocardiopsis species, $N$. exhalans sp. nov. and N. umidischolae sp. nov. Appl Environ Microbiol 67, 4293-4304.
Saitou, N. \& Nei, M. (1987). The neighbor-joining method: a new method for reconstructing phylogenetic trees. Mol Biol Evol 4, 406-425.

Sato, M., Beppu, T. \& Arima, K. (1983). Studies on antibiotics produced at high alkaline pH. Agric Biol Chem 47, 2019-2027.

Schippers, A., Bosecker, K., Willscher, S., Spröer, C., Schumann, P. \& Kroppenstedt, R. M. (2002). Nocardiopsis metallicus sp. nov., a metal-leaching actinomycete isolated from an alkaline slag dump. Int J Syst Evol Microbiol 52, 2291-2295.

Shirling, E. B. \& Gottlieb, D. (1966). Methods for characterization of Streptomyces species. Int J Syst Bacteriol 16, 313-340.

Stackebrandt, E. \& Goebel, B. M. (1994). Taxonomic note: a place for DNA-DNA reassociation and 16S rRNA sequence analysis in the present species definition in bacteriology. Int J Syst Bacteriol 44, 846-849.

Staneck, J. L. \& Roberts, G. D. (1974). Simplified approach to identification of aerobic actinomycetes by thin-layer chromatography. Appl Microbiol 28, 226-231.

Waksman, S. A. (1961). The Actinomycetes, vol. II. Classification, Identification and Descriptions of Genera and Species. Baltimore: Williams \& Wilkins.

Waksman, S. A. (1967). The Actinomycetes. A Summary of Current Knowledge. New York: Ronald Press.

Wayne, L. G., Brenner, D. J., Colwell, R. R. \& 9 other authors (1987). International Committee on Systematic Bacteriology. Report of the ad hoc committee on reconciliation of approaches to bacterial systematics. Int J Syst Bacteriol 37, 463-464.

Williams, S. T., Goodfellow, M., Alderson, G., Wellington, E. M. H., Sneath, P. H. A. \& Sackin, M. J. (1983). Numerical classification of Streptomyces and related genera. J Gen Microbiol 129, 1743-1813.

Yassin, A. F., Galinski, E. A., Wohlfarth, A., Jahnke, K.-D., Schaal, K. P. \& Trüper, H. G. (1993). A new actinomycete species, Nocardiopsis lucentensis sp. nov. Int J Syst Bacteriol 43, 266-271.

Yassin, A. F., Rainey, F. A., Burghardt, J., Gierth, D., Ungerechts, J., Lux, I., Seifert, P., Bal, C. \& Schaal, K. P. (1997). Description of Nocardiopsis synnemataformans sp. nov., elevation of Nocardiopsis alba subsp. prasina to Nocardiopsis prasina comb. nov., and designation of Nocardiopsis antarctica and Nocardiopsis alborubida as later subjective synonyms of Nocardiopsis dassonvillei. Int J Syst Bacteriol 47, 983-988. 